\title{
A gyermek- és serdülőkori depresszió tünetei, megjelenési formái és kezelése
}

\author{
Depression among children and adolescent - symptoms, \\ appearance and treatment
}

Szerzők: $\quad \begin{aligned} & \text { Németh Adrienn } \varangle \text {, Pálinkás-Holovits Zsuzsanna, Sándor Piroska } \\ & \text { Nemzeti Népegészségügyi Központ, Budapest }\end{aligned}$

Beküldve: 2020. 04. 03.

doi: $\quad$ 10.24365/ ef.v61i2.588

Összefoglaló: A gyermek- és serdülőkorban természetes fejlődési sajátosságoktól, az úgynevezett normatív identitáskrízisektől sokszor nehezen elkülöníthető a kezelést igénylő, depreszsziós epizód. Pubertáskorban normálisak és gyakoriak a rosszkedvvel, ingerlékenységgel, ingadozó hangulattal járó időszakok, ezek azonban önálló tünetként nem merítik ki a depreszszió kritériumait. A szomorúság, a boldogtalanság érzése az emberi természet és a normális érzelmi fejlődés része. Gyakori az életkorral is összefüggő hangulatváltozás, ingerlékenység. Fontos azonban felismerni a tünetek súlyosságát, intenzitását, időbeli fennállását és a funkciókárosodás (tanulmányi zavarok, kortárscsoportba való beilleszkedés zavarai stb.) mértékét ahhoz, hogy szükség esetén megfelelő segítséget kaphasson az érintett gyermek. A szülők, tanárok és kortársak sokszor nem ismerik fel időben, ha egy gyermek vagy kamasz depresszióban szenved a gyermekkorban változatosan előtérbe kerülő tünetek miatt. Ráadásul számos elterjedt és nagyon káros tévhit létezik a depresszióval kapcsolatban is, mely miatt sokszor félnek a fiatalok és a szülők az esetleges megbélyegzéstől. Ilyen, gyakran előforduló tévhitek lehetnek például, hogy a depresszió nem igényel kezelést; elég lehet a környezetváltozás, pihenés; „csak össze kell szednie magát” a fiatalnak. Az alábbi összefoglalóban részletesen bemutatjuk a gyermek- és serdülókori depresszió sajátosságait, tüneti megjelenési formáit, valamint a lehetséges kezelési módokat, teendőket.

Kulcsszavak: depresszió; hangulatzavar; öngyilkosság; tünetek; kezelés

Summary: Depression in childhood and adolescent age is often difficult to recognize since it presents with various symptoms commonly very similar to behaviors naturally occurring in normative crises of this age such as identity crisis. In puberty, episodes of low and changeable mood, irritability are often present as part of development but these alone do not fulfill the criteria of depression. In general, sadness and mood changes are part of the emotional development and important aspects of human nature. What is important in identifying clinical depression is the intensity and severity of the symptoms, how long are they present and the level of disruption in functionality (for example: difficulties in studying and concentration, disruption of social connections) caused by the symptoms. It is often difficult for a parents or teachers to recognize the various symptoms of depression, in addition to the wide spread misconceptions and biases in connection to depression often prevent caregivers or adolescents to ask for help. Deciding whether the child or adolescent has depression and needs professional help is always a professional question, thus it is advised to see a psychologist or psychiatrist in case of worrying or disruptive symptoms. In the following summary concerning depression in childhood and adolescence, we attempt to give a detailed description of the various symptoms of depression in different age groups, possible treatment approaches, and steps to take for caregivers.

Keywords: depression; mood disorders; suicide; symptoms; treatment 


\section{BEVEZETÉS}

Mindannyian éreztük már magunkat szomorúnak, lehangoltnak, lehet, hogy életünk egy szakasza kivételesen nehéz volt valamilyen esemény vagy helyzet miatt. Ilyen események lehetnek például szeretteink halála, válás, barátaink, szerelmünk elvesztése, csalódás. A veszteség, szomorúság, kilátástalanság érzése bénító súllyal nehezedhet hétköznapjainkra, és szinte mindent negatív fényben tüntethet fel. Amikor az elóbbiekhez hasonló veszteségek után a hangulatváltozás tartósan fennáll, a tünetek intenzívebbé válnak és megnehezítik a személy mindennapi életvitelét, az a depresszió kialakulását jelzi.

Serdülők esetében különösen sérülékeny időszakok fordulnak elő a fejlődés során. A legtipikusabb élettani fejlődési krízis a gyermekből felnőtté válás kapcsán a mindenkit érintő identitáskeresés. Ez az időszak a labilis hormonális és testi változások mellett olyan gondolkodásbeli és érzelmi változásokat idéz elő a gyermekek életében, amelyek önmagukban is jelentős hangulatingadozást, ingerlékenységet eredményeznek. Elvont fogalmakról kezdenek gondolkodni, az élet és halál kérdései ebben az életkorban fogalmazódnak meg legmeghatározóbban. Keresik a helyüket a világban, a kortársak között, próbálgatják a felnőtt szerepeiket, párválasztáson, pályaválasztáson gondolkoznak, és ekkor kezdik a saját családjukhoz füződő viszonyulásukat is átértékelni. Tulajdonképpen ezek a területek alkotják a serdülők identitásának pilléreit, amelyek komolyabb krízisbe sodorhatják a fiatalokat akkor, amikor ezek közül több területen is problémákkal szembesülnek.

Gyakran alakulhatnak ki gyermekeknél és serdülőknél krízishelyzetek, amikor új közösségekbe, új élethelyzetbe kerülnek, a szüleik válnak, vagy egy szeretett személyt elveszítenek. A költözés, a barátok elvesztése, a szülők anyagi problémái, a barátokkal való vita, a szerelmi csalódás, az erőszak, a szexuális erőszak, a komoly testi betegség vagy más pszichés problémák fennállása is teremthet ilyen helyzeteket. ${ }^{1}$

A depressziós állapot a hangulat zavara. Jellemzője, hogy tartósan fennáll, és a környezet változásai nem vagy alig befolyásolják. Ilyenkor mindenképp szakember segítségére van szükség.

\section{A gyermekkori depresszió előfordulása Magyarországon}

A depresszió és az öngyilkosság nagymértékben átfedik egymást és súlyos népegészségügyi problémákat jelentenek Európában. ${ }^{2,3}$

Az unipoláris major depresszió az egyik leggyakoribb pszichiátriai betegség Magyarországon a felnőtt lakosság körében: 15,1\% az élettartam prevalencia, 7,1\% az 1 éves prevalencia. Havonta mintegy 200000 felnőtt fordul szakemberhez major depresszió tüneteivel hazánkban. ${ }^{4,5}$

A depresszív zavarok gyakoriak 18 év alatt is. Gyermekkorban 1-2\%, serdülókorban 3-8\% az előfordulása, vagyis száz gyerekből, egy átlagos iskolai évfolyamból 3-8 gyereket érint. ${ }^{6}$

Fontos kiemelni, hogy a felnőttkori major depreszszió leggyakrabban fiatal felnőttkorban (25-35 év) vagy serdülőkorban indul. A disztímia (tartós minor depresszió) jellemző kezdete 12-16 év közé tehető. $\mathrm{Az}$ esetek felében családi halmozódás figyelhető meg (de fontos tudni, hogy csak 37\% a genetikai meghatározottság, sokkal jelentősebb az összetett gén-környezet interakció szerepe a betegség kialakulásában). ${ }^{7}$

A kezeletlen depresszió több mint 50\%-ban társul szorongásos zavarral, hiperaktivitás és figyelemzavarral, magatartászavarral vagy szerhasználattal. ${ }^{8}$ A hangulatzavarral küzdő páciensek ellátásának fejlesztése hatékony megközelítésnek tekinthető az öngyilkosság megelőzésében is, ugyanis a kezeletlen depresszióval küzdő páciensek gyakrabban követnek el öngyilkosságot a társadalom más populációihoz képest. ${ }^{9}$

A magyar serdülők körében a második leggyakoribb halálozási ok a befejezett öngyilkosság, és világviszonylatban vezető helyen állunk. ${ }^{10}$

A „Fiatal Életek Megmentése és Felvértezése” (Saving and Empowering Young Lives in Europe SEYLE) elnevezésű nemzetközi kutatás szerint a magyar fiatalok 12\%-a foglalkozott életében az öngyilkosság gondolatával, 10\%-uknak voltak kifejezett szuicid gondolataik, és 3\%-uk kísérelt meg öngyilkosságot életében. A SEYLE vizsgálat Magyarországon végzett felmérése alapján 14 éves kor alatt 1:100 000 a befejezett öngyilkosságok aránya, míg 14-19 éves kor között 10:100 000 az öngyil- 
kosság miatt bekövetkező halálozások aránya. A fiúk ebben az életkorban négyszer gyakrabban követnek el öngyilkosságot, mint ellenkező nemü társaik, azonban a lányok esetében több a szuicid kísérlet. ${ }^{11,12}$

Öngyilkosságot elkövető, illetve megkísérlő fiataloknál - felnőttekhez hasonlóan - több mint 90\%-ban fennáll valamilyen pszichiátriai betegség, és csupán 5-20\%-uk áll ekkor pszichiátriai kezelés alatt. 10,13,14 Az öngyilkosságot elkövető, megkísérlő gyermekeknél leggyakoribb pszichiátriai betegség a depresszió, a második leggyakoribb ok a pszichoaktív szerhasználat. $^{15}$

Fontos megemlíteni az öngyilkossági rizikófaktorok sorában - szintén minden korosztálynál - azt, hogy ha valaki korábban már megkísérelt öngyilkosságot. ${ }^{16}$ A befejezett öngyilkosságot elkövetők közel harmada kísérelt meg korábban öngyilkosságot. ${ }^{17}$

\section{HOGYAN ISMERHETEM FEL, HA EGY GYERMEK DEPRESSZIÓVAL KÜZD?}

A gyermekkori depresszió felismerése és a kezelés korai megkezdése nemcsak a gyermek és a család jelenlegi életében, de a későbbi tünetek és súlyos következmények megelőzése szempontjából is kiemelt jelentőségü.

Fontos tehát idejében felismerni a hangulatzavarra utaló tüneteket, melyek gyermekek esetében életkoronként eltérő jellegzetességeket, megjelenési formákat mutatnak.

Általában elmondhatjuk, hogy minél fiatalabb egy gyermek, annál nagyobb mértékben térnek el tünetei a felnőttkori depresszió klasszikus hangulati tüneteitől, amelyek első ránézésre akár ellentétes képet is mutathatnak (túlzott aktivitás, dührohamok).

A következő táblázatban életkori bontásban is megtalálhatók a depresszióra jellemző tünetek:

1. táblázat: A depresszióra jellemző tünetek életkori felosztásban

\begin{tabular}{|c|c|c|}
\hline $\begin{array}{l}\text { Óvodáskor (3-6 év) } \\
\text { jellegzetes tünetei }\end{array}$ & $\begin{array}{l}\text { Kisiskolás kor (7-14 év) } \\
\text { jellegzetes tünetei }\end{array}$ & $\begin{array}{c}\text { Kamaszkor és ifjúkor (15-25 év) } \\
\text { jellegzetes tünetei }\end{array}$ \\
\hline $\begin{array}{l}\text { - } \text { könnyen ingerült és hangulatilag } \\
\text { labilis, agresszivitás előfordul. } \\
\text { - csökkent érdeklődés a játék és } \\
\text { a mozgás iránt. } \\
\text { - szomorú arckifejezés. } \\
\text { - } \text { mimika és gesztikuláció } \\
\text { csökkent. } \\
\text { - az örömképesség csökkenése. } \\
\text { - introvertált viselkedés akkor is, } \\
\text { ha agresszió is jelen van. } \\
\text { - táplálkozási zavar, a testsúly } \\
\text { csökkenése vagy növekedése. } \\
\text { - alvászavarok, rémálmok, } \\
\text { elalvás-átalvás zavarai. } \\
\text { - bevizelés (enuresis). } \\
\text { - széklettartási zavarok } \\
\text { (encopresis). } \\
\text { - } \text { gyakori önvád: „engem nem } \\
\text { szeret senki, nem játszik velem } \\
\text { senki stb.” }\end{array}$ & $\begin{array}{l}\text { - } \text { agitáltság, ingerlékenység. } \\
\text { - verbális beszámoló a rossz } \\
\text { hangulatról. } \\
\text { - öngyilkossági gondolatok } \\
\text { megjelenhetnek. } \\
\text { - szorongás attól, hogy a szülők } \\
\text { nem figyelnek rájuk eléggé. } \\
\text { - iskolai teljesítményzavarok. }\end{array}$ & $\begin{array}{l}\text { - izgatottság, ingerlékenység és } \\
\text { agresszivitás. } \\
\text { - szociális visszahúzódás. } \\
\text { - csökkent önbizalom. } \\
\text { - önvád. } \\
\text { - apátia, szorongás. } \\
\text { - koncentrációs zavar. } \\
\text { - iskolai teljesítményzavar. } \\
\text { - önsértés, öngyilkossági } \\
\text { gondolatok, intenciók. } \\
\text { - a nap folyamán az állapot } \\
\text { hullámzása. } \\
\text { - pszichoszomatikus zavarok. } \\
\text { - étkezési zavarok. } \\
\text { - deviáns viselkedésformák. }\end{array}$ \\
\hline
\end{tabular}

Forrás: EAADi, OSPlii táblázata nyomán, $2009^{18}$

'European Alliance Against Depression (EAAD) - Európai Szövetség a Depresszió Ellen program

iiptimizing Suicide Prevention Programs and Their Implementation in Europe (OSPI) - Többszintű akcióprogram a depresszió és öngyilkosság megelőzésére 
Tünetek csecsemő és kisgyermekkorban (0-6 év)

Számos tanulmány és megfigyelés támasztja alá azt a tényt, hogy a gyermekek már csecsemőkortól „utánozzák” anyjuk negatív hangulatát. Ilyen szempontból is különösen fontos a gyermekágyi depreszszió megfelelő kezelése, hiszen az édesanya alacsony fekvésú hangulata, csökkent válaszkészsége a gyermek testi és érzelmi fejlődésére egyaránt hatással van. A depresszióval küzdő anyák gyermekei kisdedkorban kevesebb pozitív érzelmet osztanak meg szüleikkel, érzékenyebben reagálnak a környezet változásaira. Szomorúság, fáradékonyság, önbizalomhiány alakul ki a kisgyermekek esetében a gyakori, negatív anyai megjegyzések pedig önvádláshoz, önbizalomhiányhoz vezetnek. ${ }^{19,20}$

Kisgyermekeknél jellemzően olyan szomatikus tünetekben ölt formát a depresszió, mint például a fokozott szenzitivitás, ingerlékeny viselkedés, hoszszan tartó szomorúság, sírás, megmagyarázhatatlan fejfájás, hasfájás. ${ }^{21}$

Óvodáskorban fő tünet az alvás és étvágy zavarai, a szégyen érzése, a pszichomotoros tevékenység zavara. Önmegnyugtatásként, örömforrásként megjelenhet a nemi szervek fokozott érintése, maszturbálás. Gyakori a játék vagy egyéb tevékenységek élvezetének hiánya vagy képtelensége, az erős és általános búntudat, az extrém fáradtság és kimerültség, a kognitív teljesítmény visszaesése. Mindezekkel együtt gyakori a szociális visszahúzódás, fokozott félénkség, a fantázia hiánya. A depressziós gyermekeket éppúgy jellemezheti a passzivitás, mint a pszichomotoros nyugtalanság (ide-oda szaladgálás minden cél nélkül). Felfokozott agresszív tendenciák is jelzői lehetnek depressziónak, akár a másik, akár saját maga ellen irányuló formában (pl. a falba veri a fejét). Előfordulhat visszaesés a már elért képességek terén, például bevizelés (enuresis), bekakilás (encopresis). ${ }^{22,23}$

Tünetek gyermek- (6-10 év) és prepubertás (10-12 év) korban

A fenti tünetek nagy része megjelenik gyermekkorban is, sőt sok esetben a prepubertásban is előfordulhatnak. Ebben az életkorban is vezető tünet lehet a hosszan tartó irritabilitás, lehangoltság, szomorúság, az étvágy hullámzásai, még látványo- sabban jelentkezhet a szociális visszavonulás, az opponáló (ellenálló) viselkedés, és megjelenhet az önsértés. A gyermekkor és prepubertás során is gyakran jelentkeznek szomatikus tünetek, mint a hasfájás és fejfájás.

Ritkábban megfigyelhetünk agitált, tartósan izgatott viselkedést, visszatérhet a kisgyermekkorban normális szeparációs szorongás. Súlyos esetekben, nagyon ritkán előfordulhatnak hanghallások, hallucinációk is.

A depresszió következményei közül ki kell emelni a koncentrációs készség és a teljesítőképesség romlását, a tanulmányi eredmények visszaesését, lemaradást a szociális fejlődésben. A depresszió felismerésének hiányában gyakran tartják a beteg gyermeket egyszerúen lustának és butának. ${ }^{22}$

Elhangozhatnak ezekben az életkorokban csökkent önbizalomra, értéktelenség érzésére utaló kijelentések is, amelyekre mindig érdemes odafigyelni. llyenek lehetnek pl. „Engem senki sem szeret."; „Senki sem akar velem játszani."; "Mindig én vagyok az, aki hibát követ el."; "Bárcsak meg se születtem volna."

A fenti tipikus mondatok is illusztrálják, hogy depresszió hatására már ebben a korban is megjelenhet a halál, illetve az öngyilkosság gondolata, bár fiatalabb gyerekeknél sokszor nem konkrét formában (pl. mi lenne, ha ő maga nem létezne, vagy balesetet szenvedne és meghalna). Ezekkel a gondolatokkal minden esetben foglalkoznunk kell!

\section{Tünetek serdülőkorban (12-18 év)}

A serdülőkorú gyermek tünetei már jobban hasonlítanak a felnőttkori depresszió jeleihez, azonban a lehangoltság helyett sokszor ingerlékeny hangulat jellemzi őket. ${ }^{21}$ Legfőbb tünetek: a lehangoltság vagy irritábilitás, a tépelődés, a motiváció hiánya, a kiábrándultság, az agresszivitás, az önhibáztatás, az önbizalom hiánya, a szociális izoláció és az érdektelenség érzése. Depressziós serdülők gyakran viselkednek visszahúzódóan barátaikkal, szüleikkel, tanáraikkal, ami még izoláltabbá teszi őket. Serdülőkori depresszióban is jellemző az iskolai teljesítmény romlása, amelyet a környezet sokszor nemtörődömségnek vagy lustaságnak címkéz, ha az addig jól teljesítő fiatal tanulmányi eredményei romlanak, érdeklődése beszúkül. ${ }^{22}$ 
A halállal való foglalkozás egyre jellemzőbb ebben az időszakban. A visszatérő halálvágy, öngyilkossági gondolatok sokszor rejtetten is megjelenhetnek (pl. búcsúlevelet írnak, végrendeletet készítenek a fiatalok stb.). Fokozott veszélyt jelent öngyilkossági terv fontolgatása és az öngyilkosságra tett kísérletek is. Minden ilyen esetben haladéktalanul szakemberhez kell fordulni.

Bizonyos pszichés zavaroknál előfordulhat öngyilkossági szándék nélkül megjelenő önsértő magatartás is (pl. falcolás, cigarettacsikk elnyomása, bőrkapargatás stb.), melyet azonban mindig komoIyan kell venni és szakember segítségét kérni. ${ }^{24}$

A serdülókori depresszióban is jellemző a testi panaszok kialakulása, az alvászavarok, és előfordulhat a testi higiénia elhanyagolása is. Serdülőkorban a fiatalok fokozottan veszélyeztetettek a különböző testkép- és étkezési zavarok kialakulására (bulimia, anorexia), amelyek gyakran járnak együtt depresszióval, illetve szorongásos zavarokkal. ${ }^{25}$

A depresszióval küzdő fiatalok kifejezetten veszélyeztetettek alkohol- és droghasználat szempontjából. Az ily módon történő probléma megoldási kísérletek súlyosbítják a fiatal állapotát, és fokozzák a depresszió tüneteit. ${ }^{26}$

A tüneti képben van különbség gyermek és serdülőkorban a fiúk és lányok között is. Idősebb lányok esetében gyakrabban látunk depresszív hangulatot, míg fiatalabb fiúk esetében irritabilitást. Fiatal lányok gyakrabban kommunikálnak testi fájdalmakkal (fejfájás, hasfájás, végtagfájdalmak). ${ }^{27}$

\section{Milyen figyelmeztető jelek fennállása esetén kell szakemberhez fordulni?}

Abban az esetben, ha a következő tünetek közül 5 (a fő tünetek közül legalább 1) két hétig tartósan fennáll a nap nagyobb részében, és egy héten több napon át jelen vannak a tünetek, mint ahányon nem.

1. Fő tünetek:

a. depressziós (serdülőknél akár ingerlékeny) hangulat a nap legnagyobb részében.

b. a tevékenységek, játék iránti érdeklődés vagy öröm érzésének jelentős csökkenése.

2. Jelentős testsúlyváltozás (hízás vagy fogyás);
3. Alvászavarok (elalvási, átalvási zavarok, esetleg túl sok alvás);

4. Pszichomotoros agitáció vagy gátoltság (ingerlékenység, irritáltság vagy meglassultság);

5. Fáradtság vagy energiahiány;

6. Értéktelenség vagy túlzott bűntudat érzése;

7. Csökkent gondolkodási, összpontosítási vagy döntési képesség;

8. Halállal és öngyilkossággal kapcsolatos visszatérő gondolatok, öngyilkossági terv vagy kísérlet. ${ }^{28}$

A DEPRESSZIÓ egyéb megjelenési formái

(A jelenleg érvényes klasszifikációs rendszer, DSM-5 alapján)

\section{Diszruptív hangulatszabályozási zavar}

Súlyos, ismétlődő dühkitörések (verbális, cselekvéses), amelyek nincsenek arányban a helyzet vagy provokáció súlyával, időtartamával. Ezek a megnyilvánulások nem felelnek meg a fejlődési szintnek, és átlagosan hetente háromszor előfordulnak. A dühkitörések közötti időszakot állandó irritábilitás vagy dühös hangulat jellemzi.

\section{Tartósan fennálló depresszív zavar (disztimia)}

Depresszív vagy irritábilis hangulat elhúzódóan és 1 éven át tartósan fennáll, a nap nagy részében, valamint a legtöbb napon tartósan jelen van, és ez jelentős szenvedést és/vagy károsodást okoz az iskolai, szociális és egyéb tevékenységek területén. A tünetek nem lehetnek szerhasználat vagy egyéb testi betegség következményei, valamint más pszichiátriai zavar tünetei. Abban az esetben, ha az év egymást követő 2 hónapjában megszúnnek a páciens tünetei, akkor ez a diagnózis nem áll fenn. ${ }^{28}$

\section{MI ÁLLHAT A DEPRESSZIÓ HÁTTERÉBEN?}

Számos családi és egyénre jellemző rizikófaktort azonosítottak a depresszív jellegű tünetek és a depressziós megbetegedések hátterében. A családból eredő rizikófaktorok lehetnek genetikai, illetve pszichoszociális eredetűek. 
Utóbbi csoportba tartozik például a szülőkkel való kapcsolat és a kötődés minősége, a házasság, vagy szülők közti kapcsolat problémái, a gyenge családi támogatás és a diszfunkcionális szülői magatartás. Gyermekek esetén mindig érdemes figyelni a szülővel való kapcsolatra. Minél kisebb gyerekről van szó, általában annál közvetlenebbül köthetők a viselkedésszabályozás, hangulat zavarai az elsődleges gondozóval való kapcsolat minőségéhez. ${ }^{29} \mathrm{~A}$ kapcsolatot nehezítheti a szülő saját pszichológiai problémája, gyásza, nehéz élethelyzete is.

Egyéni rizikófaktorok lehetnek egyes temperamentumbeli, illetve kognitív (gondolkodásbeli) jellemzők (pl. labilis hangulat, alacsony önértékelés és negatív tendenciájú gondolatok), különbségek az érzelemszabályozás hatékonyságában, különbségek a neurobiológiai illetve fiziológiai válaszkészségben (például a stresszválasz-rendszer egyéni jellemzőiben), esetleg párhuzamosan létező egyéb pszichológiai problémák, pl. szorongásos zavarok.

A depresszió kialakulásában a fentieken kívül nagy szerep jut az életeseményeknek és környezeti tényezőknek (pl. szülő elvesztése, válás, zaklatás, bántalmazás, abúzus bármilyen formája, betegség vagy halál a családban). Nem szabad megfeledkeznünk azokról a korai negatív eseményekről sem, amelyek az idegrendszer fejlődését is nagyban befolyásolják (pl. születés körüli traumák, az anya nem megfelelő táplálkozása, bántalmazás, alkoholés/vagy drogabúzus).

Érdemes arra is odafigyelni, hogy mi történik a gyermekkel az iskolában, illetve a szabadidős tevékenységek során. Egyre többször oka a szorongásnak, a depressziónak, esetenként az öngyilkosságnak is az iskolai vagy iskolán kívüli kortárs bántalmazás (bullying), vagy annak online, a közösségi média felületein megvalósuló formája (cyber bullying).

Összességében a depresszió kialakulásához többféle rizikófaktor együttes jelenléte, illetve kölcsönhatása szükséges. ${ }^{21}$

Akkor is fontos foglalkozni a megjelenő problémákkal, ha azok éppen nem tûnnek olyan súlyosnak, vagy nem akadályozzák egyértelműen a család múködését. A segítségadás éppen akkor lehet a leghatékonyabb, amikor még preventív jellegü, a tünetek még kisszámúak és enyhék, a betegség nem alakult ki teljesen. A család életminőségében azonban nagy változást tud hozni, ha segítséget kapnak a problémák kezeléséhez, illetve a későbbi depressziós epizód megjelenését akadályozhatjuk meg ezzel.

Érdemes azt is észben tartani, hogy ha a szülők elbeszélése nyomán hallunk először egy gyermek tüneteiről, az elbeszélést nagymértékben befolyásolja a szülő aktuális érzelmi állapota. Ha éppen ijedten érkezett, elképzelhető, hogy egy felnagyított képet kapunk a problémáról, de az is lehet, hogy hosszas halogatás után szánta rá magát, esetleg szégyelli a problémákat, amikor is lehetséges, hogy egy visszafogott vagy bagatellizált elbeszélést hallunk. Fontos, hogy mindkét esetben vegyük komolyan a problémát és biztosítsuk a szülőt, hogy a megfelelő helyen segítséget kaphat.

A gyermek és serdülőkorban kezdődő depressziós epizód átlagos hossza 7-9 hónap közé tehető, természetes lefolyása szerint spontán remisszió előfordulhat, de az esetek többségében (40-60\%-ban) 2-5 éven belül újabb epizód jelentkezik. ${ }^{21}$

\section{BIZONYÍTOTTAN HATÉKONY TERÁPIÁS FORMÁK}

A depresszió manapság rendkívül jól kezelhető a megfelelő, komplex gyermekpszichiátriai terápiával. A kezelés általában megoldható ambulánsan gyermekpszichiátriai szakrendelőben. A kórházi kezelés akkor szükséges, ha:

- különösen súlyos, együtt járó pszichiátriai vagy szomatikus zavar áll fenn, amely veszélyezteti a gyermek állapotát (evészavar, szorongás, pszichózis, öngyilkossági veszély);

- az ambuláns terápiás eredmény nem kielégítő;

- nehezen elérhető a gyermek számára az ellátás;

- öngyilkossági veszély áll fenn.

A megfelelő kezeléssel megelőzhetők a visszatérő epizódok, akár felnőttkorban is és csökkenthető az öngyilkosság kockázata.

A leghatékonyabb pszichoterápiás módszerek:

Kognitív viselkedésterápia (CBT, átlagosan 10-12 ülésből áll), mely terápiás módszer jellemzően a panaszokra fókuszál. Megtanítják a gyermeket és a szülőt a tünetek kezelésére azáltal, hogy segítenek 
a gondolatokat átkeretezni, új viselkedésmintákat kialakítani, ezáltal új, hatékony megküzdési stratégiákat dolgoznak ki. A terápiás folyamat során javulnak a szociális készségek is. Formáját illetően történhet egyénileg vagy csoportosan. ${ }^{21}$ Léteznek internet alapú CBT-eszközök, amelyek lehetőséget nyújtanak arra, hogy azok a fiatalok is segítséghez jussanak, akik számára nem vagy nehezen elérhető a kognitív viselkedésterápia (www.ifightdepression.com).
Serdülők számára hatékony terápiás formák a szervezett, önismereti csoportfoglalkozások, az egyéni (interperszonális) pszichoterápia, a relaxációs technikák elsajátítása.

Gyógyszeres kezelés: bizonyos esetekben szükség lehet gyógyszeres kezelésre is a pszichoterápia mellett, ezt minden esetben alaposan mérlegeli a gyermek- és ifjúságpszichiáter szakorvos, és szoros követést javasol. ${ }^{21}$

1. ábra: A hangulatzavarok kezelése gyermek- és serdülökorban

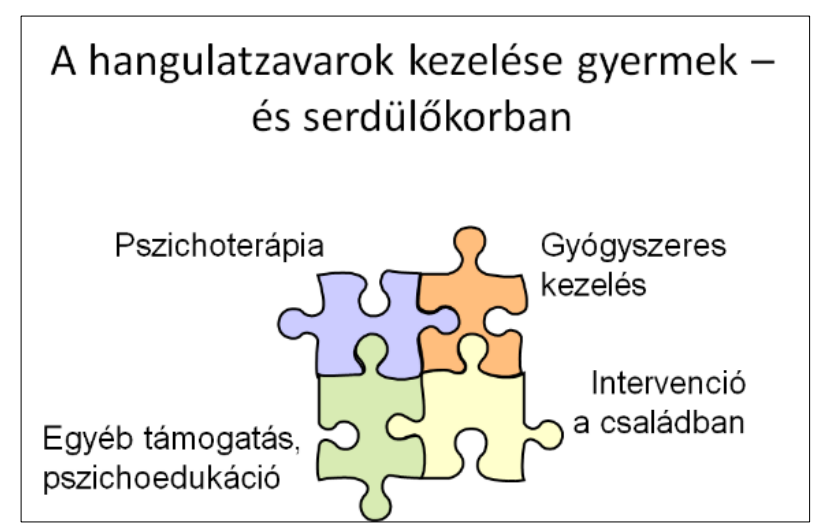

Forrás: OSPI-Europe

\section{MIT TEGYEK, HA EGY DEPRESSZIÓVAL KÜZDŐ GYERMEK SEGITTSÉGET KÉR TŐLEM?}

Minden esetben vegyük komolyan a gyermek segítségkérését, kerüljük a panaszok lekicsinylését. Hallgassuk meg a problémát egy olyan helyen, ahol biztosan nem zavarnak meg minket. Az érzéseit fogadjuk el, fejezzük ki, hogy megértjük őt, legyünk empatikusak („Szóval mostanában sokszor vannak gondjaid a barátaiddal és sokszor vagy rosszkedvü. Megértem, hogy nehéz neked most!"). Fejezzük ki, hogy örülünk annak, hogy megosztotta velünk a nehézségét, mert ez már az első lépés ahhoz, hogy megoldást lehessen találni.

Fontos, hogy mindig vegyük komolyan a gyermek problémáit, ne bagatellizáljuk azokat! Az érintett gyermek számára jelentős szenvedést okozhat olyan gondolat vagy történés is, amelyet esetleg mi felnőttként máshogy értékelünk. Ebben az esetben is nagyon fontos elismernünk, hogy látjuk, ez a dolog őt nagyon megviseli. Szintén fontos, hogy ne fessünk eléjük negatívabb képet a jövőről, ne hasonlítgassuk a gyermek érzéseit másokéhoz (kerülendők pl. a következők: „Ó, meglátod, felnőtt korodban százszor ennyi problémád lesz még! Képzeld, nekem is ennyi meg ennyi nehézségem van, mégsem vagyok depressziós...").

Miután a gyermek bizalmába fogadott bennünket és beszélt a nehézségeiről, ajánljuk fel számára, hogy szeretnénk abban támogatni, hogy minél előbb kaphasson megfelelő segítséget. Magyarázzuk el neki, hogy ehhez szükséges lesz beszélnünk a gondviselőjével, amit az ő érdekében teszünk, és kérdezzük meg, van-e olyan részlet, amit nem szeretne, hogy a szüleivel megosszunk. Mondjuk el a gyermeknek, hogy ha olyasmiről szerzünk tudomást, ami közvetlenül veszélyezteti az ő vagy mások életét, vagy törvénybe ütközik (bántalmazás, szerhasználat), akkor haladéktalanul értesítenünk kell a szüleit és további lépéseket kell tennünk annak érdekében, hogy biztonságban lehessen.

Javasolhatjuk szakember bevonását (pszichológus, klinikai szakpszichológus), iskolában például elkísérhetjük az iskolapszichológushoz, aki el tudja dönteni, hogy szükséges-e klinikai szakpszichológus felkeresése. Szaksegítség ajánlásánál törekedni kell 
a név és elérhetőség megadására vagy az intézmény nevének és pontos elérhetőségének megjelölésére, mivel minél általánosabb a küldés („,keressenek egy pszichológust"), és minél több intézményt kell megjárnia a családnak, hogy megfelelő ellátást kapjanak a problémájukra, annál nagyobb a lemorzsolódás valószínűsége.

Fontos tudni, hogy gyermekkori depressziós, illetve szorongásos tünetek jelentkezhetnek a családi környezet veszélyeztető volta miatt, például elhanyagolás, bántalmazás következményeként is. Amennyiben ennek gyanúja felmerül, a szakember (egészségügyi vagy pedagógus) felelőssége és egyben törvényi kötelezettsége is, hogy a gyermekvédelmi jelzőrendszer részeként a helyi Családés Gyermekjóléti Szolgálatnál vagy Központnál jelzést tegyen. ${ }^{30}$

\section{KOMMUNIKÁCIÓ A SZÜLŐKKEL}

Ahhoz, hogy a gyerek és a család eljusson a megfelelő helyre, ahol segítséget kaphatnak, tapintatosan rá kell világítani a problémára. Meg kell értetni a szülővel, hogy a gyermek vagy a család tünetei mögött betegség állhat, amelyen lehet segíteni, ha időben jelentkeznek a megfelelő helyen, ahol pontos diagnózist és megfelelő kezelést kaphatnak. Mivel a gyermekek tünetei jelezhetik a család nem megfelelő múködését, illetve súlyos családi problémákat is, ezért a szülők félhetnek a terápiától és az azzal járó esetleges változástól. Ilyen esetekben fokozott szerepe van a bizalmi légkör kialakításának, a folyamatos kapcsolattartásnak, kommunikációnak. Érdemes ezekben az esetekben a segítségkérés útjának pontos nyomon követése (pl. visszajelzés kérése a szülőtől, utánkövetés).

\section{ÖSSZEFOGLALÁS}

A fentiekben ismertettük a depresszió előfordulásának gyakoriságát gyermekek és serdülők körében Magyarországon, majd részleteztük a hangulatzavar tüneteit és megjelenési formáit életkori csoportokra bontva. Foglalkoztunk a depresszió hátterében álló tényezőkkel, valamint a bizonyítottan hatékony terápiás lehetőségekkel. Gyakorlati tanácsokkal szolgáltunk felnőtteknek arra az esetre, ha egy gyermek hangulati probléma miatt kérne segítséget, valamint a szülőkkel való kommunikáció sajátosságait is tárgyaltuk.

A gyermekkori- és serdülőkori depresszióval kapcsolatos ismereteknek az egészségügyi szakemberek mellett a szülők, pedagógusok, egyéb segítő foglalkozású szakemberek, valamint a gyermekek és fiatalok számára is jelentőségük van. Amennyiben a kórképpel potenciálisan kapcsolatba kerülők rendelkeznek a számukra szükséges, hiteles ismeretekkel, ez jelentősen hozzájárulhat ahhoz, hogy a depresszió időben felismerésre kerüljön, az érintettek minél hamarabb eljussanak a megfelelő ellátáshoz, adekvát kezelésben részesülhessenek, ezáltal a súlyosabb és krónikussá váló kimenetek megelőzhetőek legyenek, valamint az öngyilkosság rizikója is csökkenjen.

\section{HIVATKOZÁSOK}

\footnotetext{
${ }^{1}$ Hajduska M. Krízislélektan. ELTE Eötvös K, Budapest, 2012.

${ }^{2}$ Lönnquist J, Valtonan HM, Haukka J. Outcome of patients with major depressive disorder after serious suicide attempt. J Clin Psychiatry. 2009;70(10):1372-1378. doi: 10.4088/JCP.09m05110blu.

${ }^{3}$ Ystgaard M, Arensman E, Hawton K, at al. Deliberate self-harm in adolescents: comparison between those who receive help following self-harm and those who do not. J Adolesc. 2009;32(4):875-91. DOI: 10.1016/j.adolescence.2008.10.010 ${ }^{4}$ Rihmer Z, Angst J. Mood disorders - Epidemiology In Kaplan and Sadock's Comprehensive Textbook of Psychiatry 9th Edition. (Sadock BJ, Sadock VA, Ruiz P edition), 2009.

${ }^{5}$ Szádóczky E, Papp Z, Vitrai J. et al. A hangulat és szorongásos zavarok előfordulása a felnőtt magyar lakosság körében, Orvosi Hetilap. 200;141:17-22
} 
${ }^{6}$ Costello EJ, Mustillo S, Erkanli A, et al. Prevalence and development of psychiatric disorders in childhood and adolescence. Arch Gen Psychiatry. 2003;60:837-844. DOI: 10.1001/archpsyc.60.8.837

${ }^{7}$ Rihmer Z, Szekeres Gy, Bai-Nagy K. Depressziós zavarok In A pszichiátria magyar kézikönyve

(Füredi J, Németh A szerkesztette) Medicina Könyvkiadó, Budapest, 2015.

${ }^{8}$ del Rey R, Elipe P, Ortega-Ruiz R. Bullying and cyberbullying: overlapping and predictive value of the co-occurrence. Psicothema. 2012;24(4):608-613.

${ }^{9}$ Mann JJ, Apter A, Bertolote J, et al. Suicide Prevention Strategies: A Systematic Review. JAMA. 2005;294(16):20642074. doi:10.1001/jama.294.16.2064

${ }^{10}$ Balazs J, Lecrubier Y, Csiszer N, et al. Prevalence and Comorbidity of Affective Disorders in Persons Making Suicide Attempts in Hungary: Importance of the First Depressive Episodes and of Bipolar II Diagnoses. J Affect Disord. 2003;76:113-119. DOI: 10.1016/s0165-0327(02)00084-8

${ }^{11}$ Wasserman C, Hoven CW, Wasserman D. et al. Suicide Prevention for Youth - A Mental Health Awareness Program: Lessons Learned from the Saving and Empowering Young Lives in Europe (SEYLE) Intervention Study. BMC Public Health. 2012;12:776. DOI: 10.1186/1471-2458-12-776

12 Balázs J. Serdülőkori mentális egészségfejlesztő program a középiskolákban: A YAM program bemutatása. Gyermekgyógyászat. 2017;68:352-357.

${ }^{13}$ Gould MS, Greenberg T, Velting DM, at al. Youth suicide risk and preventive interventions: a review of the past 10 years. J Am Acad Child Adolesc Psychiatry. 2003;42(4):386-405. DOI:10.1097/01.CHI.0000046821.95464.CF

${ }^{14}$ Marttunen M, Pelkonen M. Psychiatric Risk Factors for Adolescent Suicide: A Review. Psychiatria Fennica. 2000;31:110-125.

${ }^{15}$ Cherpitel CJ, Borges GL. Wilcox HC. Acute Alcohol Use and Suicidal Behavior: A Review of the Literature. Alcoholism: Clinical and Experimental Research. 2004:28(5):18-28. DOI:10.1097/01.alc.0000127411.61634.14

${ }^{16}$ Hawton K, van Heeringen K. Suicide. Review. The Lancet. 2009;373:1372-1381. DOI:10.1016/S0140-6736(09)60372-X

${ }^{17}$ Arató M, Demeter E, Rihmer Z. et al. etrospective Psychiatric Assessment of 200 Suicides in Budapest. Acta Psychiatrica Scandinavica. 1988;77:454-456. doi.org/10.1111/j.1600-0447.1988.tb05150.x

${ }^{18}$ Hegerl U, Wittenburg L, Arensman E, et al. Optimizing Suicide Prevention Programs and Their Implementation in Europe (OSPI Europe): an evidence-based multi-level approach. BMC Public Health. 2009;9:428 doi.org/10.1186/14712458-9-428

${ }^{19}$ Kopp M, Berghammer R (szerk.) Orvosi pszichológia, Medicina.Könyvkiadó Zrt. Budapest, 2004

${ }^{20}$ Kopp M, Kovács M (szerk.) A magyar népesség életminısége az ezredfordulón. Semmelweis Kiadó, Budapest, 2006

${ }^{21}$ Kapornai K, Vetró Á. Hangulatzavarok. In. Balázs J., Miklósi M. (editor). A gyermek- és ifjúkor pszichés zavarainak tankönyve. Semmelweis Kiadó, Budapest, 2015;91-100.

${ }^{22}$ Oláh R. A hangulati élet zavarai gyermek és serdülőkorban. In: Vetró Á, William, LI., Parry-Jones (szerk). Gyermek és ifjúságpszichiátria. Szeged: Gyermekeink Lelki Egészségéért Dél-Magyarországi Alapítvány és Szent Györgyi Albert Orvostudományi Egyetem. 1996;183-196.

${ }^{23}$ Luby JL. Early Childhood Depression. Am J Psychiatry. 2009;166(9):974-979. doi.org/10.1176/appi.ajp.2009. 08111709

${ }^{24}$ Balázs J, Kapornai K. Öngyilkosság gyermek- és serdülőkorban. In: Kalmár S., Németh A. \& Rihmer Z. (eds) Az öngyilkosság orvosi szemmel. Budapest, Medicina. 2012;124-136.

${ }^{25}$ Pászthy B. A táplálkozási magatatás zavarai. In: Balázs, J. \& Miklósi, M. (szerk) A gyermek- és ifjúkor pszichés zavarainak tankönyve. Budapest: Semmelweis Kiadó, 2015

${ }^{26}$ Demetrovics Zs, Koronczai B. A gyermek- és ifjúkor pszichés zavarainak tankönyve. In: Balázs, J. \& Miklósi, M. (szerk) Budapest: Semmelweis Kiadó, 2015.

${ }^{27}$ Baji I. A gyermekkori depresszió jellegzetességei a tünetek, a komorbiditások és az életminőségre gyakorolt hatás tekintetében, PhD értekezés tézisei, Szeged, 2011.

${ }^{28}$ American Psychiatric Association (2013) Diagnostic and Statistical manual of mental disorders, (DSM-5 $\left.{ }^{\circledR}\right)$. American Psychiatric Pub. Magyar kiadás: DSM-5 referencia kézikönyv a DSM-5 diagnosztikai kritériumaihoz. Oriold és Társai Kft, 2014.

${ }^{29}$ Sexson SB, Glanville DN, Kaslow NJ. Attachment and depression. Implications for family therapy. Child Adolesc Psychiatr Clin N Am. 2001;10(3):465-86.

${ }^{30}$ Módszertani útmutató. A gyermekvédelmi észlelő- és jelzőrendszer múködtetése kapcsán a gyermek bántalmazásának felismerésére és megszüntetésére irányuló szektorsemleges egységes elvek és módszertan. Elérve: 2020.03.30.

https://kk.gov.hu/download/e/60/c0000/A\%20gyermek\%20bántalmazásának\%20felismerésére\%20és\%20megszüntetésére\%20irányuló\%20egységes\%20elvek\%20és\%20módszertan.pdf 